\title{
OPTIMASI RESPON GERAKAN KAPAL IKAN CATAMARAN TERHADAP GELOMBANG REGULLER
}

\author{
Romadhoni \\ Jurusan D-III Teknik Perkapalan, Politeknik Negeri Bengkalis \\ Email $^{1}$ : romadhoni@polbeng.ac.id
}

\begin{abstract}
This study was conducted to determine if the motion performance catamaran-type fishing boat, through the vessel response to beam waves of sea, sea and head following sea causing oscillation motion in six degrees of freedom. Boats were used as models are aboard ship optimization results comparison with the size of the main LBP $16.0 \mathrm{~m} ; \mathrm{B} 6.0 \mathrm{~m}$; T H $4.0 \mathrm{~m}$ and $1.5 \mathrm{~m}$. Ship modeled using the program maxsurf dongle, then the model is analyzed using Seakeeper to know RAO vessels such as heaving, rolling and pitching. Input data such as speed boats, heading angle and the type of wave spectrum to show the information entered for the vessel response. RAO's big heave motion maximum occurs at a speed of 14 knots towards $180^{\circ}$ with RAO value of $3.389 \mathrm{~m} . \mathrm{m}^{-1}$ at a frequency of $0.41 \mathrm{rad} . \mathrm{s}^{-1}$, the maximum value is $135^{\circ}$ of the roll angle of attack occurs when the ship's speed is $0 \mathrm{~m}^{-1} . \mathrm{s}^{-1}$ with a value of RAO $1.34 \mathrm{deg} . \mathrm{m}^{-1}$ at a frequency of $1.67 \mathrm{rad} . \mathrm{s}^{-1}$, while the value of the minimum roll occurs at a speed of 14 knots with an incidence angle of $135^{\circ} R A O$ value 2,096 deg. $\mathrm{m}^{-1}$ at frequency 1:11 rad/s and maximum use values pith occurred on the ship's speed of 14 knots with an incidence angle of $180^{\circ} \mathrm{RAO}$ value of $5.66 \mathrm{deg} . \mathrm{m}^{-1}$ at frequency 1:27 rad.s $\mathrm{s}^{-1}$. From the research results can be conclude that fish-boat this type of catamaran has a good performance while operating at sea. Keywords : catamaran, ecounter frequency, MAXSURF, RAO, seakeeping.
\end{abstract}

\begin{abstract}
ABSTRAK
Penelitian ini dilakukan untuk mengetahui performa olah gerak kapal ikan tipe katamaran, melalui respons kapal terhadap gelombang beam sea, following sea dan head sea yang menimbulkan gerakan osilasi dalam 6 derajat kebebasan. Kapal yang dijadikan sebagai model adalah kapal hasil optimisasi kapal pembanding dengan ukuran utama LBP 16,0 m; B 6,0 m; H 4,0 m dan T 1,5 m. Kapal dimodelkan dengan menggunakan program MAXSURF, kemudian model dianalisa dengan menggunakan Seakeeper untuk mengetahui RAO kapal seperti heaving, rolling, dan pitching. Data input seperti kecepatan kapal, sudut heading dan tipe spektrum gelombang dimasukkan untuk dapat menampilkan informasi respons kapal. Besar RAO untuk gerak heave maksimum terjadi pada kecepatan 14 knot arah $180^{\circ}$ dengan nilai RAO sebesar $3,389 \mathrm{~m} / \mathrm{m}$ pada frekuensi $0,41 \mathrm{rad} / \mathrm{s}$, nilai roll maksimum terjadi sudut datang gelombang $135^{\circ}$ saat kecepatan kapal $0 / \mathrm{ms}$ dengan nilai RAO 1,34 deg/m pada frekuensi 1,67 rad/s, sedangkan nilai roll minimum terjadi pada kecepatan 14 knot dengan sudut datang $135^{\circ}$ nilai RAO $2.096 \mathrm{deg} / \mathrm{m}$. pada fekuensi $1.11 \mathrm{rad} / \mathrm{s}$ dan nilai pith maksimum terjadi pada kecepatan kapal 14 knot dengan sudut datang $180^{\circ}$ nilai RAO $5.66 \mathrm{deg} / \mathrm{m}$ pada fekuensi $1.27 \mathrm{rad} / \mathrm{s}$. Dari hasil penelitian dapat disimpulkan kapal ikan jenis katamaran ini memiliki performa yang baik saat beroperasi dilaut.
\end{abstract}

Kata kunci : katamaran, frekuensi encounter, MAXSURF, RAO, seakeeping.

\section{PENDAHULUAN}

Kapal merupakan salah satu struktur terapung yang bergerak pada permukaan air laut. Setiap struktur yang mengapung dan bergerak di atas permukaan laut akan mengalami gerak osilasi. Gerak osilasi ini didefeniskan sebagai gerak bolak balik benda di sekitar titik setimbang dengan lintasan yang sama dan terjadi secara periodik yaitu berulang dalam rentang waktu yang sama. Benda yang mengalami gerak osilasi dianggap benda kaku padat (perfectly rigid body) dan terapung di permukaan air baik dalam keadaan tenang (still/calm water) atau dalam keadaan terganggu (disturbed water). Sebagai sebuah benda kaku, kapal dipersiapkan untuk menghadapi berbagai kondisi ekstrim seperti cuaca yang tidak menentu dan berubah-ubah ketika melakukan operasi pelayaran di laut. Ada berbagai gaya luar (eksternal force) dan gaya dalam (internal force) yang dialami oleh kapal setiap beroperasi. Ini menyebabkan badan kapal mengalami gaya yang menimbulkan tegangan dan regangan secara tetap dan berulang. Dengan demikian, sebuah kapal 
baru harus mampu bertahan (survive) mengatasi kondisi tersebut agar umur kapal semakin lama. Gaya luar yang dialami oleh kapal perikanan saat melakukan aktivitas penangkapan ikan di laut di antaranya adalah gelombang laut, angin, penambahan gaya-gaya akibat operasi penangkapan, lebar kandas, muatan yang dipindahkan melewati kapal dan benturan kapal dengan dermag atau dengan kapal perikanan lainnya. Sedangkan gaya-gaya internal misalnya berat kapal itu sendiri, muatan yang dipindahkan dalam kapal dan juga terjebaknya air di kapal. [1].

Secara singkat, timbulnya gerakan kapal tersebut dikarenakan oleh lingkungan operasi kapal di sekitarnya yaitu gelombang laut. Gelombang laut menyebabkan kapal memberikan respon berupa gerakan kapal atau olah gerak kapal (seakeeping). Dengan demikian tujuan penelitian ini adalah melakukan simulasi respon gerakan kapal terhadap arah gelombang melalui software Seakeeper. Data kapal yang digunakan adalah hasil penelitian sebelumnya.

\section{TINJAUAN PUSTAKA}

\section{Gerak Kapal (Seakeeping)}

Seakeeping adalah gerakan kapal yang dipengaruhi oleh gaya-gaya luar yang disebabkan oleh kondisi air laut. Seakeeping dibedakan menjadi 3 yaitu : 1. Heaving adalah gerakan kapal yang sejajar sumbu $\mathrm{Z}$ dan saat terjadi heaving kapal mengalami naik turun secara vertikal. 2. Pitching adalah gerakan kapal yang memutari sumbu Y, ketika terjadi pitching kapal mengalami perubahan trim bagian bow dan stern secara bergantian. 3. Rolling adalah gerakan kapal yang mengelilingi sumbu $\mathrm{X}$, ketika terjadi rolling bagian sisi kanan kapal bergerak ke sebelah bagian sisi kiri kapal yang terulang secara bergantian.

\section{METODE}

Sudut masuk gelombang yang dimaksud disini adalah arah datang gelombang yang diukur dari bagian-bagian kapal. Pada penelitian ini sudut masuk gelombang ditinjau dari 5 (lima) arah yang secara garis besar merepresentasikan arah gelombang ketika menerpa badan kapal saat beroperasi di perairan.

Tabel 1. Number of Wave Heading

\begin{tabular}{|c|c|c|}
\hline No & Wave Heading $\left(^{\circ}\right)$ & Description \\
\hline 1 & 0 & Following Seas \\
\hline 2 & 45 & Stern Quartering Seas \\
\hline 3 & 90 & Beam Seas \\
\hline 4 & 135 & Bow Quaertering Seas \\
\hline 5 & 180 & Head Seas \\
\hline
\end{tabular}

Setelah menentukan sudut masuk gelombang, penulis melakukan pehitungan Response Amplitude Operator (RAO) pada kapal katamaran. Untuk menindak lajut tentang penggunaan powering kapal di Pulau Bengkalis dengan kecepatan 14 knot. Analisa seakeeping kapal merupakan analisa yang meliputi gerak kapal akibat datangnya gelombang mengarah ke kapal seperti $\left(0^{\circ}, 45^{\circ}, 90^{\circ}, 135^{\circ}\right.$ dan $\left.180^{\circ}\right)$ serta untuk lebih jelas bisa lihat Gambar di bawah ini:

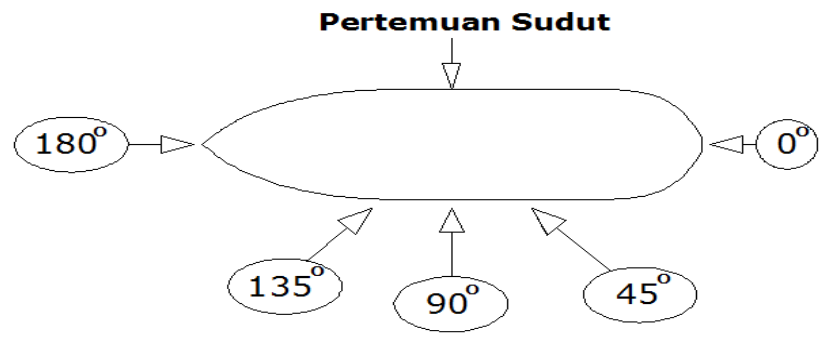

Gambar 1. Sudut pertemuan gelombang datang ke kapal 
Selain sudut datangnya gelombang dalam analisa gerak kapal juga tidak terlepas dari perhitungan pada pembahasan gerakan kapal seperti berikut :

\section{Gerakan pitching}

Gerakan pitching merupakan gerak kapal yang menyebabkan terjadinya trim kapal baik haluan maupun buritan yang secara bergantian dan gerakan ini dapat dianalisa dengan formula sebagai berikut:

$$
\mathrm{dë}+\mathrm{e} \theta+\mathrm{h} \Theta \quad=\mathrm{M}_{0 .} \operatorname{Cos} \omega_{\mathrm{e}} \mathrm{t}
$$

dimana :

$\begin{array}{ll}\text { Inertial Moment } & =d \frac{d^{2} x \theta}{d t^{2}} \\ \text { Damping moment } & =e \frac{d \theta}{d t} \\ \text { Restoring moment } & =h \Theta \\ \text { Exciting moment } & =M_{0} \operatorname{Cos} \omega_{e} t\end{array}$

\section{Gerakan heaving}

Gerakan heaving merupakan gerakan kapal secara naik turun atau secara vertikel kapal. Untuk menganalisa dapat digunakan formula sebagai berikut:

$$
\mathrm{az}+\mathrm{bż}+\mathrm{cz}=F_{0} \operatorname{Cos} \omega_{e} t
$$

\section{Dimana :}

Inertial Force $\mathrm{F}_{\mathrm{a}}=\mathrm{az̈}$

Damping Force $\mathrm{F}_{\mathrm{b}} \quad=\mathrm{bz}$

Restoring Force $\mathrm{Fc} \quad=\mathrm{cz}$

Exiciting Force $=F_{0} \operatorname{Cos} \omega_{e} t$

\section{Gerakan Rolling}

Gerakan rolling merupakan gerakan kapal yang mengelilingi sumbu axis, ketika terjadi rolling secara longitudinal pada bagian sisi kanan kapal bergerak ke sebelah bagian sisi kiri kapal yang terulang secara bergantian. Untuk menganalisa gerakan rolling kapal, maka dapat digunakan formula sebagai berikut:

$$
a \frac{d^{2} \emptyset}{d t}+a \frac{d \emptyset}{d t}+c \emptyset=M_{o} \cos . \omega_{e} . \mathrm{t}
$$

Dimana :

Inertial Moment $a \frac{d^{2} \emptyset}{d t}$

Damping moment $a \frac{d \emptyset}{d t}$

Restoring moment $c \varnothing$

Exciting moment $M_{o} \cos . \omega_{e} . \mathrm{t}$

\section{Penentuan Spektrum Gelombang}

Pada saat melakukan perhitungan olah gerak kapal (seakeeping) yang perlu ditentukan bagi seorang desainer, harus menentukan spektrum gelombang yang mendekati atau sesuai dengan perairan dimana penelitian ini di lakukan, oleh karena itu peneliti harus bisa menentukan spektrum gelombang yang telah tersedia di dalam program Seakeeper-Maxsurf berdasarkan spektrum gelombang yang telah tersedia, maka penulis menentukan jenis spektrum gelombang yang digunakan adalah JONSWAP (Joint North Sea Wave Project).

Untuk keterangan JONSWAP ini merupakan formula yang menentukan aturan tentang data gelombang laut, seperti tinggi gelombang, rata-rata tinggi gelombang dan kecepatan angin serta penjelasan lain mengapa menggunakan spektrum gelombang JONSWAP adalah Spektrum ini cocok untuk perairan dangkal, perairan pantai dan perairan tertutup. Cukup jelas dengan adanya 
penjelasan ini, bahwa perairan di Pulau Bengkalis merupakan perairan yang tergolong pada perairan tertutup, sehingga sebelum menggunakan Spektrum gelombang JONSWAP dalam menganalisa gerak kapal (seakeeping), sehingga menghasilkan luasan motion pitch, motion heaving dan motion rolling. Dari hasil luasan motion yang dihasilkan dapat ditarik kesimpulan bahwa spectrum JONSWAP yang lebih baik sehingga tercapai kenyamanan kapal yang maksimal dengan catatan data yang dimasukkan untuk analisa gerak kapal (seakeeping) sama atau sesuai dengan perairan yang ada di Pulau Bengkalis.

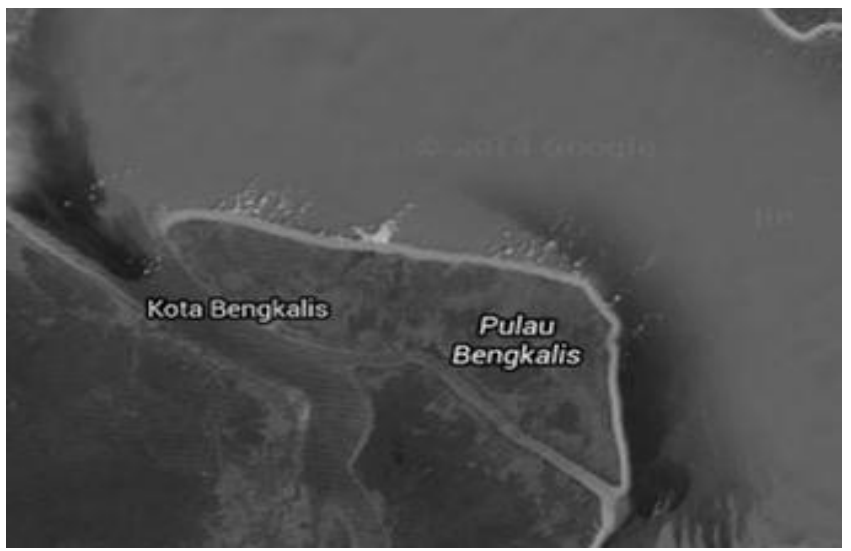

Gambar 2. Lokasi perairan di pulau Bengkalis.

Berdasarkan ketentuan tentang sea state yang terdapat pada WOCE Upper Ocean Thermal Data June (2002) dan World Meteorological Organisation (WMO) menyetujui kode standart sea state, maka perairan yang terkait pada penyeberangan di Pulau Bengkalis diasumsikan tergolong pada code sea state 2 dengan tinggi gelombang 0,1 - 0,5 meter untuk lebih jelasnya bisa dilihat Tabel (2) di bawah ini:

Tabel 2. Data sea state WOCE dan WMO

\begin{tabular}{|c|c|c|c|c|}
\hline \multirow{2}{*}{$\begin{array}{c}\text { Sea } \\
\text { State } \\
\text { Code }\end{array}$} & \multicolumn{2}{|c|}{$\begin{array}{c}\text { Significant Wave } \\
\text { height } \\
\text { meter }\end{array}$} & Description & \multirow{2}{*}{$\begin{array}{c}\text { Period } \\
\text { (s) }\end{array}$} \\
\cline { 2 - 3 } & Range & Mean & & \\
\hline 0 & 0 & 0,0 & Calm (glassy) & 10 \\
1 & $0,0-0,1$ & 0,1 & Calm (glassy) & 11 \\
2 & $0,1-0,5$ & 0,3 & Smooth (wavelets) & 12 \\
3 & $0,5-1,25$ & 0,9 & Sligth & 13 \\
4 & $1,25-2,5$ & 1,9 & Moderate & 14 \\
5 & $2,5-4,0$ & 3,3 & Rough & 5 \\
6 & $4,0-6,0$ & 5,0 & Very rough & 6 \\
7 & $6,0-9,0$ & 7,5 & High & 7 \\
8 & $9,0-14,0$ & 11,5 & Very high & 8 \\
9 & Over 14,0 & Over 14,0 & Phenomenal & 9 \\
\hline
\end{tabular}

Untuk mengetahui respon gerak kapal terlebih dahulu menentukan propertis perairan yang berada di Pulau Bengkalis dengan asumsi data karakteristik perairan sebagai berikut:

Tabel 3. Data asumsi karakteristik gelombang

\begin{tabular}{|l|c|c|c|}
\hline $\begin{array}{c}\text { Deskripsi } \\
\text { Gelombang }\end{array}$ & $\begin{array}{c}\text { Kecepatan } \\
\text { Angin } \\
\text { (Knot) }\end{array}$ & $\begin{array}{c}\text { Tinggi } \\
\text { Gelombang } \\
\text { (meter) }\end{array}$ & $\begin{array}{c}\text { Periode } \\
\text { Gelombang } \\
\text { (s) }\end{array}$ \\
\hline Moderate & 10 & 2,5 & 14 \\
\hline
\end{tabular}

Sumber : untuk kecepatan angin berdasarkan perkiraan cuaca di Bengkalis 01Mei 2015. 
Dari data Tabel 3 barulah bisa dilakukan perhitungan Spektrum gelombang dapat dilkukan pada kapal ikan, sehingga dengan spektrum JONSWAP dapat dihitung dengan formula pendekatan sebagai berikut:

$S(\omega)=\alpha g^{2} \omega^{-5} \exp \left[-1,25\left(\frac{\omega}{\omega_{0}}\right)^{-4}\right] \gamma^{\exp \left[\frac{-\left(\omega-\omega_{0}\right)^{2}}{2 \tau^{2} \cdot \omega_{0}^{2}}\right]}$

Dimana :

$S(\omega) \quad=$ Spektrum gelombang

$\gamma \quad=$ parameter puncak (peakedness parameter), bervariasi antara 1,0 s.d. 7,0.

$\tau=$ Parameter bentuk (shape parameter) Untuk $\omega \leq \omega_{0}=0,07$ dan $\omega \geq \omega_{0}=0,09$.

$\alpha=0,0076\left(X_{0}\right)-0,22$, untuk $X_{0}$ tidak diketahui $\alpha=0,0081$

\section{HASIL DAN PEMBAHASAN}

\section{Pemodelan Kapal Ikan Katamaran}

Setelah ukuran utama kapal ikan katamaran didapatkan maka selanjutnya dilakukan pemodelan sehingga diperlukan perangkat lunak untuk mendesain gambar tersebut. Adapun perangkat lunak yang digunakan ialah Maxsurf pro dan Auto CAD, penggambaran dengan menggunakan maxsurf pro ini ialah untuk mendesain bentuk lambung kapal dimana akan didapatkan bentuk body plan kapal, sheer plan kapal, half breadth plan, dan bentuk perspektif dari kapal yang diesain tesebut.

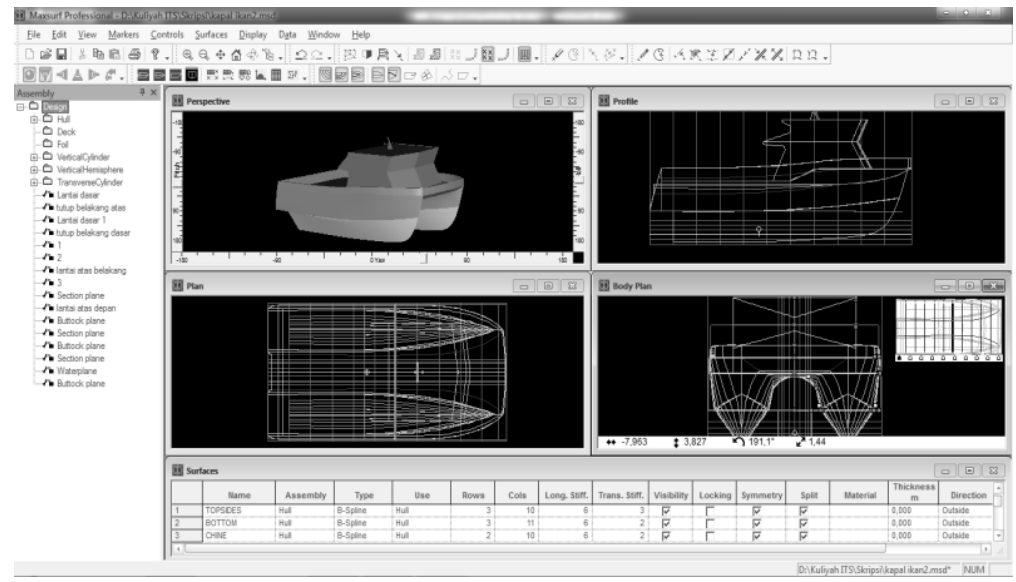

Gambar 3. Tampilan software MAXSURF-PRO

\section{Olah Gerak Kapal (Seakeeping)}

Perhitungan gerak kapal (seakeeping) kapal dilkukan dengan menggunakan program Seakeeper-Maxsurf pada kapal ikan katamaran di Pulau Bengkalis yang bertujuan untuk melihat nilai seakeping kapal serta menganalisa bentuk gelombang yang terjadi pada saat kapal dioperasikan di wilayah yang sesuai dengan penelitian ini dilakukan.

Arah datangnya gelombang mempengaruhi sudut heading $(\mu)$, yaitu sudut antara arah pergerakan gelombang dan arah laju kapal. Pengaturan sudut masuk gelombang (Wave Heading) di software Maxsurf Seakeeper Version 20. dapat dilihat pada ilustrasi gambar dibawah ini. Dari keterangan ini perlu juga dilihat berapa nilai Response Amplitude Operator (RAO). Kemudian dari hasil running perhitungan olah seakeeper pada program MAXSURF didapatlah nilai Response Amplitude Operator (RAO) pada kapal ikan katamaran sebagai berikut : 


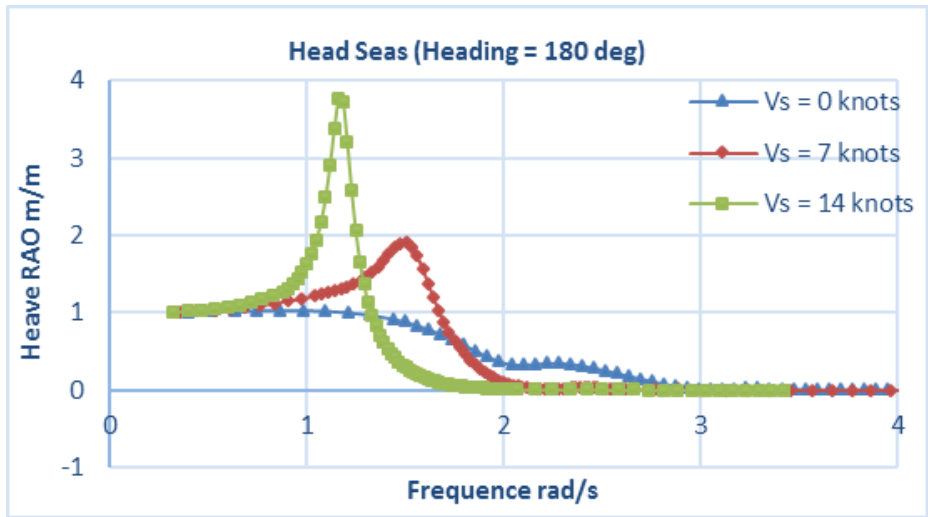

Gambar 4. Heave RAO, Head Seas (Heading = $180 \mathrm{deg}$ ) bedasarkan kecepatan.

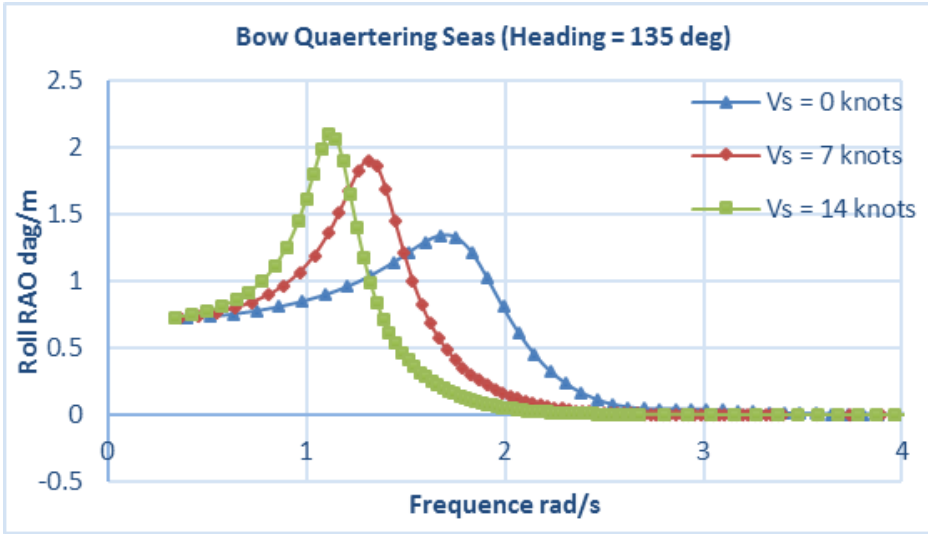

Gambar 5. Roll RAO, Bow Quaertering Seas (Heading = 135 deg) bedasarkan kecepatan.

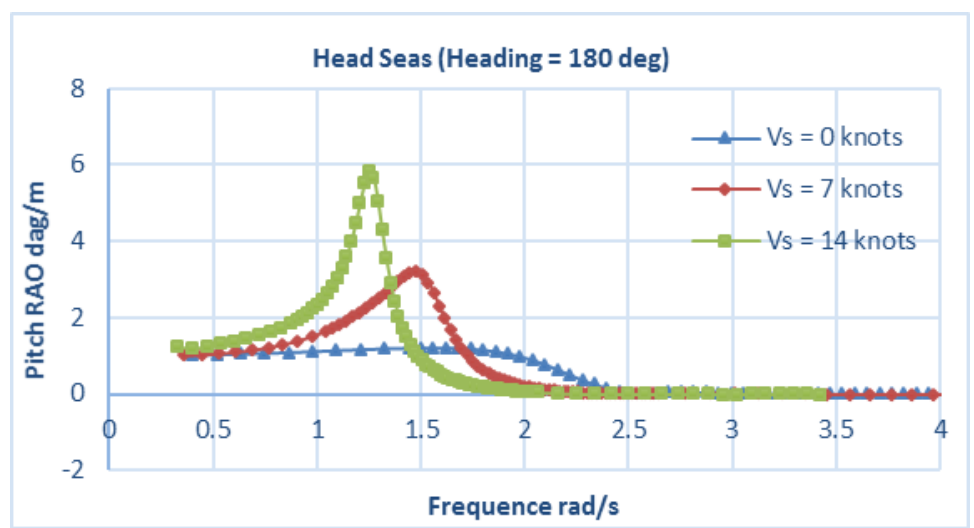

Gambar 6. Pitch RAO, Head Seas (Heading $=180 \mathrm{deg}$ ) bedasarkan kecepatan untuk nilai have, roll dan pitch pada sudut masuk gelombang $\left(\mu=0^{0} ; 45^{0} ; 90^{\circ}: 135^{\circ}\right)$.

\section{Spektrum Gelombang JONSWAP}

Berdasarkan formula di atas adalah spectrum wave memberikan gambaran untuk menghitung gerak kapal (seakeeping) secara manual sedangkan pada penelitian ini dilakukan perhitungan gerak kapal (seakeeping) dengan menggunakan Seakeeper yang terdapat pada program Maxsurf, maka dengan menggunakan spektrum JONSWAP didapatlah hasil running perhitungan spektrum gelombang berupa heaving, rolling dan pitching pada kapal ikan. 


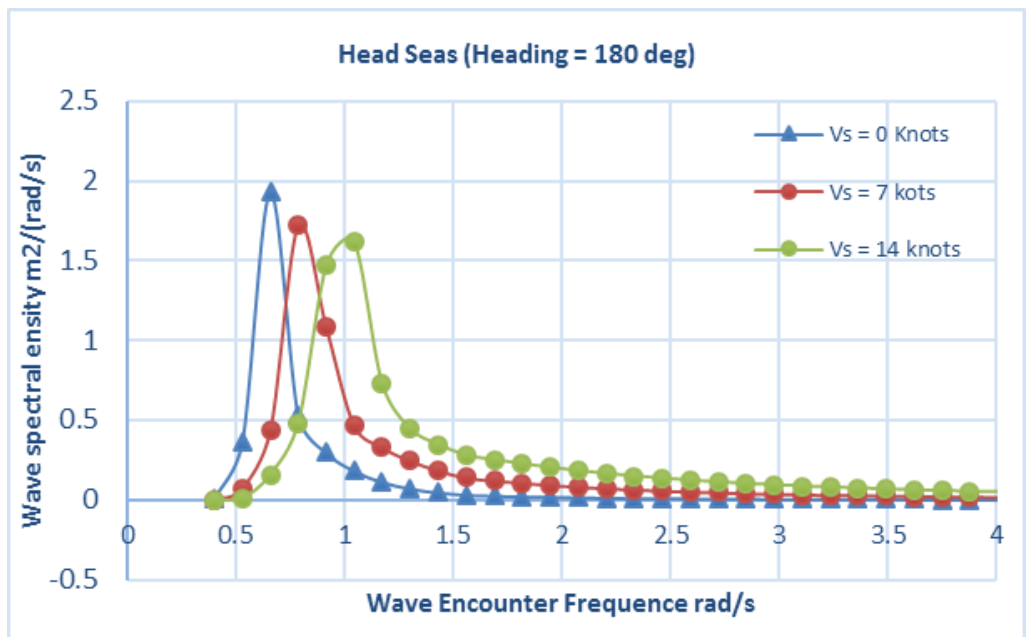

Gambar 7. Hasil Spektrum gelombang pada kecepatan 0 knots $\left(\mu=180^{\circ}\right)$

Untuk nilai spectrum wave $S(\omega)$ pada sudut masuk gelombang $\left(\mu=0^{0} ; 45^{0} ; 90^{0}: 135^{0}\right)$.

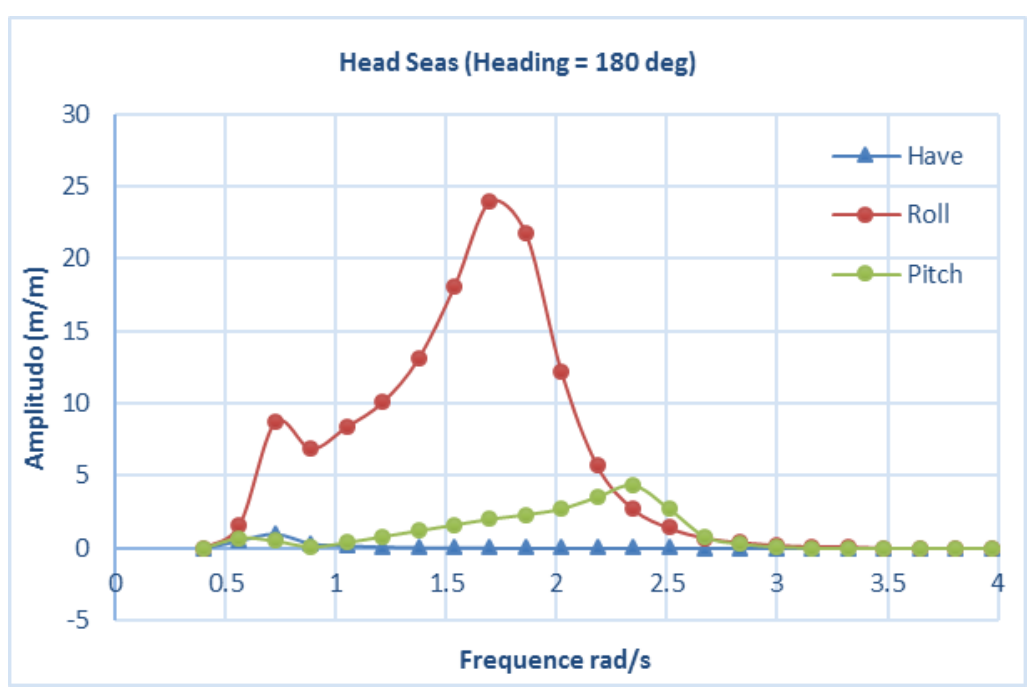

Gambar 8. Hasil respon spektrum gelombang

Analisa RAO pada arah gelombang $180^{\circ}$ (Vs $=14$ knots) pada kondisi fuel load, Gambar 8 menunjukkan bahwa semakin besar frekuensi gelombang maka semakin kecil amplitudonya. Dimana pada kondisi Roll saat frekuensi kecil menunjukkan respon amplitudo yang besar, tetapi berbanding terbalik dengan kondisi Heave dan pitch ,frekuensi bertambah maka menimbulkan respon amplitudo semakin kecil. 


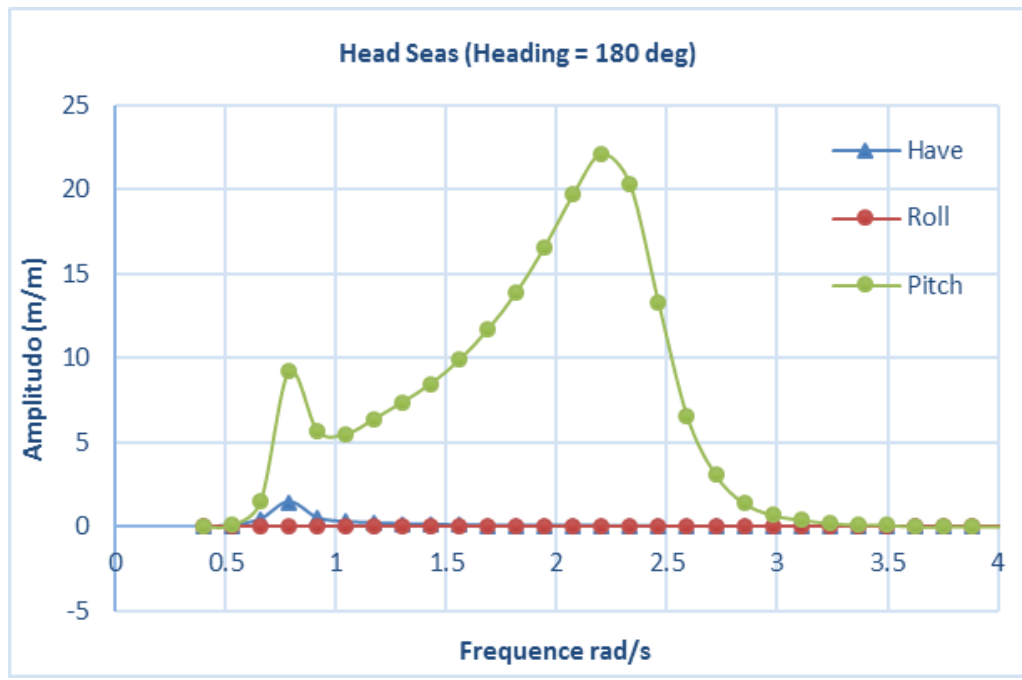

Gambar 9. Hasil respon spektrum gelombang

Analisa RAO pada arah gelombang $180^{\circ}$ (Vs = 7 knots) pada kondisi fuel load, Gambar 9 menunjukkan bahwa semakin besar frekuensi gelombang maka semakin besar juga amplitudonya. Dimana pada kondisi pitch saat frekuensi besar menunjukkan respon amplitudo yang besar, tetapi pada kondisi have dan roll tidak mengalami perubahan yang signifikan.

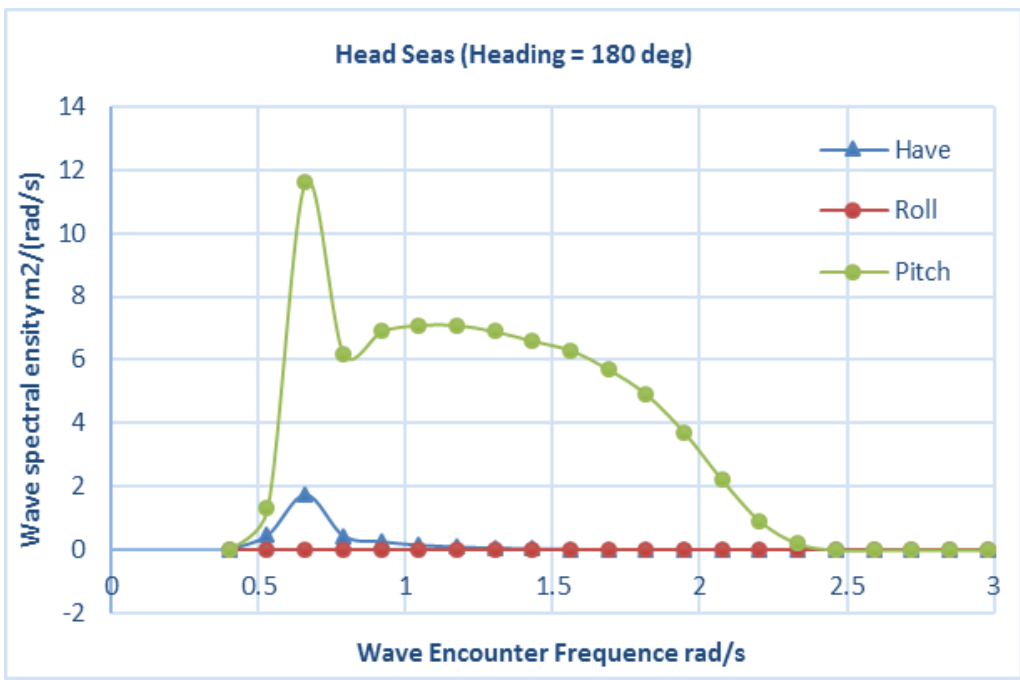

Gambar 10. Hasil respon spektrum gelombang

Analisa RAO pada arah gelombang $180^{\circ}$ (Vs $=0$ knots) pada kondisi fuel load, Gambar 10 menunjukkan bahwa semakin besar frekuensi gelombang maka semakin besar juga amplitudonya. Dimana pada kondisi Pitch saat frekuensi besar menunjukkan respon amplitudo yang besar, tetapi pada kondisi Have dan Roll tidak mengalami perubahan yang signifikan.

\section{KESIMPULAN}

Karakteristik gerakan model kapal ikan katamaran pada gelombang regular dipengaruhi oleh kecepatan, arah gelombang. Hasil analisis RAO model kapal ini adalah sebagai berikut:

1. Untuk gerak heave terjadi kenaikan nilai gerakan seiring dengan bertambahnya kecepatan kapal. Nilai gerakan heave maksimum terjadi pada saat kecepatan 14 knot kondisi sudut datang gelombang $180^{\circ}$ dengan nilai RAO sebesar $3,389 \mathrm{~m} / \mathrm{m}$ pada frekuensi $0,41 \mathrm{rad} . \mathrm{s}^{-1}$.

2. Terjadi kenaikan nilai gerakan roll seiring dengan bertambahnya kecepatan kapal. Nilai roll maksimum terjadi sudut datang gelombang $135^{\circ}$ saat kecepatan kapal $0 \mathrm{~m} . \mathrm{s}^{-1}$ dengan nilai 
RAO 1,34 deg.m ${ }^{-1}$ pada frekuensi 1,67 rad. $\mathrm{s}^{-1}$, sedangkan nilai roll minimum terjadi pada kecepatan 14 knot dengan sudut datang $135^{\circ}$ nilai RAO $2.096 \mathrm{deg} / \mathrm{m}$ pada fekuensi 1,11 $\operatorname{rad} . \mathrm{s}^{-1}$.

3. Untuk gerak pith terjadi kenaikan nilai gerakan seiring dengan bertambahnya kecepatan kapal Nilai pith maksimum terjadi pada kecepatan kapal 14 knot dengan sudut datang $180^{\circ}$ nilai RAO 5.66 deg. $\mathrm{m}^{-1}$ pada fekuensi $1.27 \mathrm{rad} . \mathrm{s}^{-1}$.

\section{DAFTAR PUSTAKA}

[1] Bhattacharyya, R. (1978), Dynamics Of Marine Vehicles, John Wiley \& Sons, New York.

[2] Djatmiko, E.B. 2012. "Perilaku dan Operabilitas Bangunan Laut di Atas Gelombang Acak". ITS-Press. Surabaya. Inonesia.

[3] Lewis, V.E. (1998), Principles of Naval Architecture Second Revision, Volume II • Resistance, Propulsion and Vibration The Society of Naval Architects and Marine Engineers 601 Pavonia Avenue, Jersey City.

[4] Watson, D.G.M. (1998), Practical Ship Design, Volume I. Oxford, UK, Elsevier Science Ltd.

[5] Sitepu, G. (1996), Gerak Kapal, Jurusan Teknik Perkapalan, Universitas Hasanuddin, Makssar.

[6] Mangasi, Hutauruk Ronald dan Pareng Rengi. (2014), Respons Gerakan Kapal Perikanan Hasil Optimisasi Terhadap Gelombang, Jurnal Perikanan Dan Kelautan ISSN 0853-7607.

[7] Watson, D.G.M. (1998), Practical Ship Design, Volume I. Oxford, UK, Elsevier Science Ltd. 
- Halaman ini sengaja dikosongkan - 